\title{
The Impact of Islamic Economics and Finance Courses on Islamic Financial Literacy
}

\author{
Mohamad Fany Alfarisi \\ Universitas Andalas \\ mfany@eb.unand.ac.id \\ Agestayani \\ Universitas Andalas \\ agestayani@yahoo.co.id \\ Silvi Delfiani \\ Universitas Andalas \\ delfiani26@gmail.com
}

\begin{abstract}
The present study seeks to investigate the impact of Islamic economics courses on Islamic financial literacy of university students. Additionally, it intends to compare Islamic financial literacy of those who have taken Islamic economics and finance courses and those who have not. With respect to the approach, the current study employed a quantitative approach to explain the linkage between the two variables. The population of the present study was all currently enrolled students of public universities in Padang particularly those from the faculty of economics and business. A self-administered questionnaire had been used to collect primary data. From the total distributed questionnaire, 300 of them were completed and included in the sample. As a result the respond rate is $71.3 \%$. The results show 145 respondents are in the category of having poor Islamic financial knowledge, while 155 respondents are in the category of moderate From 145 respondents with poor Islamic financial knowledge 79 respondents (66\%) have (not) taken (any) Islamic economics and finance courses. From 155 respondents with moderate financial knowledge 114 respondents (41\%) have not taken any Islamic economics and finance courses. The findings of the present study suggest that most respondents can be categorized as having moderate knowledge and attending formal Islamic economics and finance courses can positively contribute to have a greater level of Islamic financial literacy.
\end{abstract}

Keywords: Islamic economics; Islamic finance; Islamic financial literacy.

\section{INTRODUCTION}

Islamic financial literacy is deemed as one of the main requirements to increase the size of the Islamic financial industry. Given that Indonesia has the largest Muslim population in the world, it is normal to expect that Indonesian Islamic 
IQTISHADIA

13,2

According to the 2016 survey of the Indonesia Financial Services Authority (OJK) on financial literacy and financial inclusion, the Islamic financial literacy index of Indonesian consumers stood at the level of 8.11\% (Otoritas Jasa Keuangan, 2017). From the survey results, it can be inferred that among 100 individuals, only eight of them have sufficient knowledge about the Islamic financial system. Moreover, the findings imply that a low Islamic financial literacy index can lead to a poor financial literarcy in which it may finally may contribute to the small market size of the Islamic financial industry in this country.

The history of Islamic finance in Indonesia began in 1992 when Bank Muamalat Indonesia commenced its operation as the first Islamic commercial bank in the country. Recently, there are 13 Islamic commercial banks, 21 Islamic business units, and 167 Islamic rural banks (OJK, 2018). Additionally, to meet financial needs of investors and corporations, Islamic capital market was introduced in 1997. With more Islamic financial institutions and products available in financial market, it can be said that the Islamic finance is in the right path towards becoming substitute for the mainstream conventional finance.

The Indonesian government and the stakeholders of the Islamic financial system have an aspiration to elevate the rank and market share of the Islamic financial industry in the local and global financial markets. A number of initiatives and measures have been implemented to reach that objective. For instance, the government and the Indonesian Association of Islamic economists (IAEI) have set up a new body namely the National Committee of Islamic Finance (KNKS) that aims at accelerating the development of Islamic financial industry. Moreover, the government, particularly the Ministry of Religious Affairs have found a new body to manage hajj funds (BPKH). This new institution has become Muslims' hope which finally comes true.

Financial literacy is an essential element to help consumers making sound personal financial decisions namely saving, investment, and retirement plan. The ability to make an informed financial decision might assist consumers 
from making mistakes in selecting mortgages credit cards and other financial instruments. Meltzer et al., (2011) suggests that there is a strong association between failure in repaying debts and intention to suicide. Nevertheless, having sufficient personal financial skill can help someone to earn happiness in life. Moreover, had there been a significant numbers of consumers who are financially literate, we might be shielded from experiencing the stock market bubble, the credit crunch and other types of economic and financial disaster.

The concept and characteristics of Islamic finance are essentially different from the conventional mainstream finance. According to Abduh (2016), the Islamic financial system uses the teaching of Islam as the main reference. The unique philosophical foundation is known as Tawhid which contains the concept of oneness of God. Moreover, the guiding principles that govern Islamic financial system are taken from two main sources of Islamic teachings namely Al Qur'an and the Sunnah of Prophet Muhammad PBUH (peace be upon him). Unlike Islamic finance, conventional finance is purely secular in nature. Nevertheless, it is developed using the principles that are derived solely from human minds.

Given the difference between Islamic and conventional finance, there should be proper modification and adjustment in defining financial literacy within the context of Sharia. For example, financial literacy surveys normally ask about consumers' understanding on how interest rate works (Atkinson \& Messy, 2011; van Rooij, Lusardi, \& Alessie, 2007). In Islamic law (Sharia), collecting or paying interest on a loan is similar to a prohibited contract namely riba annasi'ah (usury). In view of this, the knowledge about interest rate or how interest rate works is irrelevant to the Islamic financial literacy concept. Hence, there is a need to modify financial literacy questionnaire to suit the distinct characters of Islamic finance.

With respect to the population composition, Indonesia is granted with a sizable number of those who are in the category of working age. The condition can contribute to Indonesia's economy that is also known as a demographic dividend. To gain most benefits of having such a population structure, is is required to educate and teach young generation a number of constructive skills. One important skill that can assist the young generation in making decision related to money and saving matters is financial literacy. Teaching financial education to the youth can protect them from making wrong and costly financial decisions (Lusardi, Mitchell, \& Curto, 2009). Moreover, Blue, Grootenboer, and Brimble (2014) suggests that financial literacy education is considered as a global priority these days.
The Impact of Islamic Economics and Finance

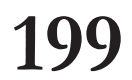


IQTISHADIA

13,2

In conjunction with the development of the Islamic finance industry, Islamic economics and finance courses have been introduced since the last two decades in Indonesia. To train the talents for the Islamic finance industry, a number of institutions notably Tazkia Institute and Muamalat Institute were the pioneers that conducted workshop and training sessions in the early phase of Islamic finance development. Additionally, these two institutes also have conducted workshops on Islamic economics and finance for academics, government officials, religious scholars and other members of Muslim community. Moreover, some higher education institutions such as Tazkia University College, Universitas Andalas (Unand), Universitas Trisakti and Universitas Islam Negeri or Institut Agama Islam Negeri (UIN or IAIN) have offered Islamic economics and finance programs for undergraduate and postgraduate levels since the 1990 os (Furqani, 2017). Until recently, more top universities notably Universitas Indonesia (UI), Institut Pertanian Bogor (IPB), Universitas Airlangga (Unair),Universitas Muhammadiyah Yogyakarta (UMY) and other private universities in the country have also offered Islamic economics and finance programs.

Table 1. Literacy Index (Based on Profession)

\begin{tabular}{llrr}
\hline No & Sector & $\begin{array}{l}\text { Conventional } \\
\text { financial literacy } \\
\text { index (\%) }\end{array}$ & \multicolumn{2}{l}{$\begin{array}{l}\text { Islamic financial } \\
\text { literacy index (\%) }\end{array}$} \\
\hline 1 & Entrepreneur & 27.6 & 6.7 \\
\hline 2 & Employee/Professional & 39.8 & 12.4 \\
\hline 3 & Students & 23.2 & 5.3 \\
\hline 4 & Housewife & 15.2 & 3.0 \\
\hline 5 & Retiree & 35.3 & 9.3 \\
\hline 6 & Unemployed and others & 22.8 & 3.7 \\
\hline
\end{tabular}

Source: National Survey on Financial Literacy and Inclusion 2016, OJK

There has been an increasing trend of the Islamic finance industry in Indonesia since the last two decades. Despite experiencing positive improvement in terms of a number of institutions, assets, revenues, and customers, Indonesian Islamic finance industry so far has not reached its most favorable level. One aspect that has led to such situation is the low score of Islamic financial literacy index. The latest survey conducted by the OJK finds that Islamic financial literacy of Indonesian consumer stood at the level of 8.11\% (Otoritas Jasa Keuangan, 2017). Moreover, the survey found that the students' Islamic financial literacy index is among the lowest compared to other consumer groups (table 1.1). It can be said that the Indonesian young generation ishaving inadequate Islamic financial knowledge. The deficiency in 
Islamic financial literacy can contribute to the low Islamic financial adoption (inclusion). Therefore, it can be a barrier to the future of Islamic finance sector development in the country.

Owing to the students' poor Islamic financial literacy index, the phenomenon needs to be observed thoroughly. The present study, therefore, intends to measure the level of Islamic financial literacy of university students and to analyze the linkage between Islamic economics and finance courses and Islamic financial literacy of university students.

\section{LITERATURE REVIEW}

The concept of Islamic financial literacy

One of early definitions of financial literacy is proposed by Norton et al (1992 in Lee, n.d.) that defines it as "the ability to make informed judgments and take effective decisions regarding the use of money management”. Other definition of financial literacy is proposed by Hung, Parker, and Yoong (2009) that defines financial literacy as a "knowledge of basic economic and financial concepts, as well as the ability to use that knowledge and other financial skills to manage financial resources effectively for a lifetime of financial well-being”. Moreover, Moore (2003) explains that financial literacy is a condition in which an individual has competency to implement his or her financial knowledge in the practical domain. Additionally, she contends that (financial) literacy is a result of knowledge and practical experience.

Financial literacy is closely related to other concepts namely financial knowledge (education), financial behavior, and financial attitude (Ahmad, Mawar, \& Ripain, 2016). Meanwhile, Moore, (2003) suggests experience as another factor that is also connected to financial literacy. Furthermore, she argues that more financial education and financial experience can make someone become more competent and sophisticated in dealing with financial matters.

Islamic finance is fundamentally different from the mainstream conventional finance. There are some negative elements in conventional finance namely riba, maysir and gharar that are prohibited by the sharia (Islamic law). Iqbal and Mirakhor (2011) suggests a number of basic principles that govern Islamic financial system notably: prohibition of interest, assetbased, risk-sharing, money as potential capital, prohibition of speculative behavior, sanctity of contracts, and preservation of property rights. In view of these fundamental differences between the two, using conventional financial literacy concept in Islamic finance context can be misleading and produce false conclusion.
The Impact of Islamic Economics and Finance

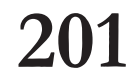


IQTISHADIA

13,2

202

With respect to the divergence between Islamic and conventional finance, there should be some adjustments and modifications in defining and constructing the Islamic financial literacy concept. For instance, basic financial literacy question normally asks about consumer's knowledge on interest rate and how interest rate works (Atkinson \& Messy, 2011; van Rooij et al., 2007). Islam clearly and strongly prohibits ribawi (usurious) transactions notably interest earned loan. Major and mainstream Islamic organizations in Indonesia notably Majelis Ulama Indonesia (MUI), Muhammadiyyah and Nahdhlatul Ulama (NU) have issued fatwas (legal opinion) that equate interest on loans with riba that is prohibited by the sharia. Thus, proper adjustment made in Islamic financial literacy concept, hopefully changes the real picture of consumers' competency on Islamic finance.

The concept of financial literacy consists of three elements namely financial knowledge, financial attitude, and financial behavior. With respect to the Islamic financial knowledge, it basically deals with how consumers understand the underlying principles of Islamic financial system. Moreover, consumers with a sufficient knowledge of Islamic finance are expected to be able to recall the Islamic financial services and how it differs from conventional finance.

The Islamic financial attitude is related to the tendency of consumers towards Islamic financial services. In other words, it contains the perspective of consumers in choosing the products ofIslamic finance over the conventional ones. Additionally, it deals with factors that drive Islamic financial services adoption. The last element of Islamic financial literacy is the Islamic financial behavior. The Islamic financial behavior means the behavior of consumers in choosing the products ofIslamic financial compared to the products of conventional finance. Accordingly, it deals with how consumers actually use or will use Islamic financial services.

One of the fundamental principles of Islamic finance is the prohibition of negative elements namely riba, gharar and maysir in the financial product and process. Riba (usury) according to the Islamic scriptures literally means "additional" or "extra. Moreover, riba is not only related to the loan transaction, but it can also be associated with any commercial transaction that is absent from exchanging equal counter-value for both contracting parties. Gharar means uncertainty. To some extent, gharar is allowed in commercial transactions. Gharar that is prohibited by scholars is the one that is known as gharar fahish. Moreover, maysir can be defined as speculative or gambling activities. We have experienced a number of financial crises as the consequences of speculative actions of investors and financial institutions in local as well as global financial market. 
Since the last two decades a number of higher education institutions in Indonesia have offered Islamic economics and finance programs. Top public Islamic Economics and Finance universities in Indonesia notably Universitas Indonesia, Insitut Pertanian Bogor, Universitas Brawijaya and Universitas Airlangga are also active in the development of Islamic finance sector by opening Islamic economics and finance program for undergraduate and postgraduate level. There are two reasons that make these institutions offer such programs, (1) idealistic reason; it is associated with the need to have a financial system that is free from negative elements such as riba, maysir and gharar, (2) market-driven reason, that is to meet the market demand for professional talents in Islamic finance industry.

Given the advancement of Islamic finance industry, the need to have sufficient Islamic financial literacy among consumers is inevitable. The consumers with adequate Islamic financial literacy would likely prefer shariacompliant financial services over the conventional ones. Additionally, they are expected to make a responsible investment decision.

In view of this, more trained professionals in Islamic banking and capital market are required to meet the dynamic of the industry. Furthermore, those professionals have to be equipped with sufficient knowledge and expertise in Islamic economics, finance and fiqh muamalah. Having the aforementioned proficiency, it can be predicted that they are able to manage the distinguished character of Islamic finance industry.

With more people having sufficient exposures to Islamic economics and finance, it might correlate with better understanding on Islamic financial related concepts particularlyits financial products, profit distribution mechanism, and contracts (aqad). The latest large scale survey on Islamic financial literacy conducted by the OJK finds that on average Islamic financial literacy index of consumers in Indonesia stood at 8.11\% level. Based on the financial services sector category, overall, Islamic financial literacy index of Indonesian consumers is lower than conventional financial literacy. The condition is similar in each financial sector that can be seen in table 2. 
IQTISHADIA

13,2

204

Table 2. Financial Literacy Index (Based on Sector)

\begin{tabular}{llcc}
\hline No & \multicolumn{1}{c}{ Sector } & Conventional (\%) & Islamic (\%) \\
\hline 1 & Banking & 28.3 & 6.6 \\
\hline 2 & Insurance & 15.7 & 2.5 \\
\hline 3 & Pension Fund & 10.9 & 0.0 \\
\hline 4 & Finance Company & 12.8 & 0.2 \\
\hline 5 & Pawn broking & 17.1 & 1.6 \\
\hline 6 & Capital Market & 4.4 & 0.0 \\
\hline
\end{tabular}

Source: National Survey on Financial Literacy and Inclusion 2016, OJK

Meanwhile, based on profession (table 2), the Islamic financial literacy index of students (high school pupils and university students) is amongst the lowest compared to the other consumer groups (based on profession).

The finding of the survey above informs that the Islamic financial literacy index of Indonesian consumers in general is very low. The highest Islamic financial literacy index is in the banking sector. Whilst, the Islamic financial literacy index in other financial sectors is extremely poor and even few sectors reached the index that is close to zero (pension fund and capital market).

Another worrying result is the poor Islamic financial literacy index of students. We believe that in the era of industrial revolution 4.0, the young generation can play a significant role in shaping the landscape of Islamic finance industry in many Muslim majority countries. However, the low figure of students' Islamic financial literacy index seems creating a major hurdle for the development of Islamic finance industry in Indonesia.

Owing to the poor Islamic financial literacy index of Indonesian consumer, the stakeholders of the industry should conduct more educational programs to improve Islamic financial literacy in society. Given that Islamic finance industry has grown rapidly; more structured and up-to-date Islamic finance education program is badly needed. The program can be an important platform to disseminate a piece of comprehensive information and understanding about the Islamic financial system and how it differs from its conventional peer. Such activity, moreover, is extremely important for high school and university students.

\section{Relevant Previous Studies}

A number of studies have been conducted to analyze the impact of financial education courses on financial behavior and decision-making of individuals. The study of Mandell and Klein (2009) examines the impact of personal financial management course on financial behavior of high school pupils in the United States of America (USA). The study finds that pupils who 
have taken personal management course are not superior in terms of financial literacy, saving-oriented and financial behavior than those who have not. In view of this, the effectiveness of financial literacy education is questionable (Mandell \& Klein, 2009).

The empirical work of Bayer, Bernheim, and Scholz, (2003) analyses the effects of financial education to employees in companies. The content of financial education in this study focuses on retirement program. The finding of the study suggests that financial education positively improves personal financial decision making of employees. In view of this, there is a strong connection between financial education and competency of employees in making financial decision.

\section{RESEARCH METHOD}

The present study aims at analyzing the impact of Islamic economics courses on Islamic financial literacy of university students. Additionally, it intends to compare Islamic financial literacy of those who have taken Islamic economics and finance courses and those who have not. With respect to the approach, the current study used a quantitative approach to explain the linkage between the two variables. The population of the present study was currently enrolled faculty of economics students from public universities in Padang notably Universitas Andalas (Unand), Universitas Negeri Padang (UNP) and Universitas Islam Negeri Imam Bonjol (UIN IB). The target respondents of the present study were students of faculty of economics and business with the study period at least three semesters. The sampling technique used was the purposive sampling method. A self-administered questionnaire was used to collect primary data from the aforementioned university students in Padang. To avoid confusion and any unnecessary errors during the survey, pre-testing was conducted to limited number of respondents. Pre-testing is another type of pilot test that focuses on data collection activities, for instance using questionnaires (Cooper \& Schindler, 2008). Having passed the pretesting stage, the next step wasto distribute the questionnaires directly to the potential respondents. Completed questionnaires, therefore were inputted to statistical software for further examinations. The data collected were analyzed using descriptive statistical tools. To find variation and impact of Islamic economics courses on Islamic financial literacy, cross tabulation technique was employed.

Prior to the real data collection, the questionnaire had been distributed to small number of respondents for pre-testing. During the pre-testing stage,
The Impact of Islamic Economics and Finance 
IQTISHADIA

13,2

some respondents were confused and misunderstood some questions in the questionnaire. Having completed some necessary revisions, the questionnaire was distributed to a large number of respondents. We distributed the questionnaire to the students of three public universities in Padang, notably Universitas Andalas (Unand), Universitas Negeri Padang (UNP), Universitas Islam Negeri Imam Bonjol(UINIB). Moreover, we assigned a number of criteria to choose the sample namely, faculty of economics and business students in public university with the length of study period at least three semesters. To collect primary data, 421 sets of self-administered Islamic financial literacy questionnaires had been distributed to the target respondents. From the total distributed questionnaire, 300 of them were completed and included in the sample. Therefore the respond rate is $71.3 \%$.

The demographic data suggest that female respondents dominate the sample space (72\%). Moreover, the majority of respondents are Muslim (99\%) and most of them are in the age of 21 (43.3\%).With respect to the family background, most respondents come from family who have high school educational background and havingmonthly income from $\mathrm{Rp} 2$ million to $\mathrm{Rp}$ 4.9 million.

\section{RESULTS}

To measure the level of respondents' Islamic financial knowledge, the students were asked to answer ten questions about the concepts and basic principles of Islamic finance and products of Islamic financial industry. The distribution of answers to Islamic financial knowledge questions can be seen in the table below.

Table 3. The Distribution of Responses to Islamic Financial Knowledge Questions

\begin{tabular}{llcc}
\hline \multirow{2}{*}{ No } & \multirow{2}{*}{ Question } & \multicolumn{2}{c}{ Response } \\
\cline { 2 - 4 } & Incorrect (\%) & Correct (\%) \\
\hline 1 & The meaning of riba & 59.7 & 40.3 \\
\hline 2 & Example of ribawi transaction & 2.0 & 98.0 \\
\hline 3 & Element of aqad & 16.3 & 83.7 \\
\hline 4 & The right aqad for a transaction & 67.0 & 33.0 \\
\hline 5 & Negative element of a transaction & 38.7 & 61.3 \\
\hline 6 & Aqad or Islamic bank saving account & 86.3 & 13.7 \\
\hline 7 & Characteristic of Islamic mutual funds & 86.3 & 13.7 \\
\hline 8 & Takaful & 43.3 & 56.7 \\
\hline 9 & Sukuk & 61.7 & 38.3 \\
\hline 10 & Mudharabah & 85.0 & 15.0 \\
\hline
\end{tabular}


From the table III above, it can be observed that most respondents The Impact of could answer the questions correctly in question number two asking about Islamic Economics the example of ribawi transaction (98\%) and the question number three and Finance about the element of aqad (contract) in a transaction (83.7\%). Meanwhile, the questions on aqad for Islamic bank saving account (6) and characteristic of Islamic mutual funds (7) are the most questions that could not be answered correctly (13.7\% for both questions).

Moreover, the respondents were classified into three categories namely, poor-knowledge, moderate-knowledge and well-knowledge. The categorization of the level of Islamic financial knowledge was based on the percentage of correct answers given by the respondents on the particular section. For instance, if a respondent is able to give three correct answers then he or she will be classified as having poor-knowledge. Overall, it is found that most respondents were able to answer four to six questions correctly (64.3\%). Hence, it can be said that the majority of respondents have sufficient (moderate) Islamic financial knowledge.

With respect to the Islamic Financial Attitude, the questions are structured to get the respondents' view about the degree of importance of using and investing in Islamic financial products. Furthermore, the responses on Islamic Financial Attitude statements were classified in an ordinal measurement scale which comprising of very important, important, somewhat important, unimportant, and very unimportant. The results suggest that the statement "placing money in an Islamic banks investment account" got the highest score amongst the 7 statements that constituted the Islamic Financial Attitude section in the questionnaire was deemed as important (64.7\%) and very important (23\%).

Table 4. The Distribution of Ranking of Factors Considered by Respondents

\begin{tabular}{lccccc}
\hline Factors & $\mathbf{1}(\mathbf{\%})$ & $\mathbf{2}(\%)$ & $\mathbf{3 ( \% )}$ & $\mathbf{4}(\%)$ & $\mathbf{5 ( \% )}$ \\
\hline Return & 27.3 & 22.7 & 15.3 & 20.0 & 14.3 \\
\hline Risk & 21.0 & 29.7 & 22.3 & 10.7 & 16.0 \\
\hline Sharia-compliant & 36.7 & 13.7 & 17.0 & 18.0 & 14.3 \\
\hline Company's reputation & 8.0 & 19.3 & 23.3 & 26.0 & 23.0 \\
\hline Service excellence & 6.7 & 14.7 & 21.3 & 25.3 & 31.3 \\
\hline
\end{tabular}

Additionally, to get more information about the Islamic Financial Attitude, the respondents were asked to rank factors they would consider beforemaking investment decisions. Those five factors are return, risk, 
IQTISHADIA

13,2

Sharia-compliant status, company's reputation, and service excellence. From the table 4, it can be seen that among the five factors, the issue of Shariacompliant got most number one ranking (36.7\%) followed by return (27.3\%) and risk (21\%). The result, therefore, suggests that many respondents put more emphasize on Sharia-compliant status of financial products prior putting their wealth in any Islamic investment schemes. In view of this, it can be said that, there is a substantial figure of university students in Padang who are deemed as Sharia-conscious consumers.

Another element of Islamic Financial Literacy is the Islamic Financial Behavior. Behavior in the present studycan be defined as how consumer actually uses any Islamic financial products. The respondents were asked to select Islamic financial products that have been used up to the present time (current proportion) and that would be used once they graduated from university and got a job. Given that our respondents are students, a number of constraints were assumed as their limitationin using Islamic financial products. Owing to this condition, the respondents were asked to choose which products that they're going to use after graduating from the university.

Table 5. Islamic Finance Products That Are Currently Used and will be Used by Respondents

\begin{tabular}{lll}
\hline Product & $\begin{array}{l}\text { Current } \\
\text { Proportion (\%) }\end{array}$ & $\begin{array}{l}\text { Future } \\
\text { Proportion (\%) }\end{array}$ \\
\hline Islamic bank saving account & 46.3 & 83.0 \\
\hline Islamic bank investment account & 6.0 & 49.3 \\
\hline Islamic bank financing & 3.3 & 27.3 \\
\hline Takaful & 1.0 & 52.7 \\
\hline Islamic stocks & 8.3 & 43.3 \\
\hline Sukuk & 1.0 & 9.3 \\
\hline Islamic mutual funds & 0.3 & 15.7 \\
\hline Waqf & 4.3 & 25.3 \\
\hline
\end{tabular}

From table 5 above, it can be seen that the respondents prefer Islamic banks saving account (46.3\%) to the other Islamic finance products. Again, considering that most respondents under the condition of not having a job or being financially dependent on parents and scholarship, it would be difficult to allocate their limited money for investment. Furthermore, a hypothetical question about which Islamic financial products would be used once they graduated and get a job was asked to the respondents. The most chosen product was Islamic bank saving account (83\%) followed by Islamic investment account (49.3\%) and Islamic stocks (43.3\%). The Islamic bank 
saving account, again, was mostly chosen by the respondents. Interestingly, the number of respondents selecting this product after graduation from university and getting a job was almost double of the current condition. That is to say, the young generation would have more commitment to use Islamic finance services after they are self-sufficient or financially independent.

One of objectives of the present study is to find the linkage between taking Islamic economics and finance courses to the level of Islamic financial literacy among university students. One relevant and critical information is about Islamic and finance courses that have been taken by the students during their study life in university.

Table 6. The Distribution Of Respondents Who Have Taken Islamic Economics and Finance Courses

\begin{tabular}{lc}
\hline \multicolumn{1}{c}{ Course } & Proportion (\%) \\
\hline Islamic Economics & 50.0 \\
\hline Islamic Banking & 40.0 \\
\hline Takaful & 27.7 \\
\hline Fiqh Muamalah & 36.0 \\
\hline Islamic Capital Market & 13.3 \\
\hline Islamic Accounting & 13.3 \\
\hline
\end{tabular}

On the table 6 above, it is found that Islamic Economics course is on top of the list which has been taken by $50 \%$ of respondents. The second and third most taken courses are Islamic Banking (40\%) and Fiqh Muamalah (36\%). Overall, $64.3 \%$ of respondents have taken at least one course and the remaining $35.7 \%$ of respondents have never taken any single course above.

It is realized that that Islamic economics and finance courses are not the sole sources information about Islamic finance. To gain more insight about Islamic finance concept and industry, people can find it from a number of alternative sources such as Islamic financial institutions' staffs, Islamic preachers, parents, friends, mass media and internet. As seen in table 7, the result finds that internet is the main sources of information about Islamic finance.

Table 7. The Source of Information about Islamic Finance

\begin{tabular}{lc}
\hline \multicolumn{1}{c}{ Source of information } & Proportion (\%) \\
\hline Islamic economics and finance courses & 67.3 \\
\hline Parents & 27.3 \\
\hline Employees of Islamic financial institutions & 25.0 \\
\hline Ustadz (preacher) & 49.7 \\
\hline High school teachers & 33.3 \\
\hline
\end{tabular}

The Impact of Islamic Economics and Finance 


\begin{tabular}{lll} 
IQTISHADIA & \multicolumn{2}{l}{14.0} \\
\cline { 2 - 3 } 13,2 & Government bodies & 39.7 \\
\cline { 2 - 3 } & Peers & 82.3 \\
\cline { 2 - 3 } 210 & Internet (news portals, social media, websites, blogs) & 28.7 \\
\cline { 2 - 2 } & Printed media (newspapers, magazines) & 40.3 \\
\cline { 2 - 2 } & Electronic media (TV, radio) &
\end{tabular}

Meanwhile, the least source of Islamic finance information is government bodies (14\%). The result is quite interesting considering that the respondents of the present study are young generation which is also known as the "millennial". Millennial are the current generation that experience more exposure of the industrial revolution 4.0. They are heavily engaged and spent more time in online activities. Owing to this phenomenon, the finding is not surprising.

\section{DISCUSSION}

The Linkage between Islamic Economics and Finance Courses and Islamic Financial Knowledge

This part is devoted to discuss about the relationship between Islamic economics and finance courses and Islamic Financial Knowledge. The hierarchical categories namely Poor-knowledge, Moderate-knowledge and Well-knowledge. Respondents who could answer o-3 questions in the Islamic Financial Knowledge correctly were grouped into the Poorknowledge category. Moreover, those who could give 4-6 correct answers were grouped into the Moderate-knowledge group. Finally, the respondents who couldanswer 7-10 questions correctly wereconsideredas having above the average knowledge about the basic of Islamic finance and were placed in the Well-knowledge group.

With respect to the Islamic economics and finance courses that have been taken by the respondents, we divided them into two groups namely those who have and have never taken any of the above mentioned courses. Using the crosstabs method, we try to find a meaningful connection between the two created variables namely Islamic Financial Knowledge level and the Islamic Economics and Finance Courses. Additionally, the Pearson Chi Square to check whether to linkage between the two variables is significant. 
Table 8. The Linkage Between Islamic Economics and Finance Courses and Islamic Financial Knowledge

\begin{tabular}{|c|c|c|c|c|}
\hline & & \multicolumn{2}{|c|}{$\begin{array}{l}\text { Islamic Economics } \\
\text { and Finance Courses } \\
\text { Group }\end{array}$} & \multirow{2}{*}{ Total } \\
\hline & & Never & $\begin{array}{l}\text { Take at } \\
\text { least one } \\
\text { course }\end{array}$ & \\
\hline \multirow{3}{*}{$\begin{array}{l}\text { Islamic } \\
\text { Financial } \\
\text { Knowledge } \\
\text { Category }\end{array}$} & Poor-knowledge & $\begin{array}{r}40 \\
(51.3 \%) \\
{[37.4 \%]}\end{array}$ & $\begin{array}{r}38 \\
(48.7 \%) \\
{[19.7 \%]}\end{array}$ & $\begin{array}{r}78 \\
(100.0 \%) \\
{[26.0 \%]}\end{array}$ \\
\hline & Moderate-knowledge & $\begin{array}{r}61 \\
(31.6 \%) \\
{[57.0 \%]}\end{array}$ & $\begin{array}{r}132 \\
(68.4 \%) \\
{[68.4 \%]}\end{array}$ & $\begin{array}{r}193 \\
(100.0 \%) \\
{[64.3 \%]}\end{array}$ \\
\hline & Well-knowledge & $\begin{array}{r}6 \\
(20.7 \%) \\
{[5.6 \%]}\end{array}$ & $\begin{array}{r}23 \\
(79.3 \%) \\
{[11.9 \%]}\end{array}$ & $\begin{array}{r}29 \\
(100.0 \%) \\
{[9.7 \%]}\end{array}$ \\
\hline Total & & $\begin{array}{r}107 \\
(35.7 \%) \\
{[100.0 \%]}\end{array}$ & $\begin{array}{r}193 \\
(64.3 \%) \\
{[100.0 \%]}\end{array}$ & $\begin{array}{r}300 \\
(100.0 \%) \\
{[100.0 \%]}\end{array}$ \\
\hline
\end{tabular}

The Impact of Islamic Economics and Finance

From the table 8 above, $64.3 \%$ of respondents have taken Islamic economics and finance courses, while the remaining respondents (35.7\%) never got any exposure of taking a formal Islamic economics and finance learning process. Furthermore, the majority of respondents are in the category of moderate-knowledge (64.3\%).

In the category of poor knowledge, the difference between the two groups can be said as insignificant. Moreover, in the category of moderate knowledge and well knowledge, the group of respondents with the exposure of getting a formal Islamic economics and finance education is much better than the other group that has not experienced such exposure. The result of Pearson chi square corroborates the figure on the table 8 which suggests the difference amongst groups did not happen by chance. In other words, it is a result of the variable namely formal Islamic economics and finance courses. In view of this, the courses can be said as putting a significant impact upon the Islamic Financial Knowledge of university students.

The Linkage between Islamic Economics and Finance Courses and Islamic Financial Attitude

Two different sets of questionnaire have been used to observe the tendency of respondents towards using Islamic financial products. In the first set of 
IQTISHADIA questionnaire, seven statements were given to the respondents using five 13,2 scale ranging fromvery unimportant, unimportant, somewhat important, important and very important. The respondents can select each of the fivescale that best represents their view and preference on particular statements. The second set of questionnaire contains a number of factors that can be considered by the respondents prior making investment decision. Therefore, they were asked to rank those factors accordingly.

The crosstab approach was used to analyze the relationship between taking formal Islamic Economics and Finance Courses and the Islamic Financial Attitude. The first statement is about "save money in Islamic bank saving account". $61 \%$ of respondents view the statement as "important" and $32.7 \%$ of respondents think that it is "very important". The majority of those who view the statement as important or very important are the respondents who have taken Islamic Economics and Finance courses. Similar pattern of responses can also be found in other six statements. However, the Pearson chi square suggests that the difference among groups is statistically insignificant.

The second part of the Islamic Financial Attitude questionnaire is about factors that would be considered before making investment decision. The general result in table V suggests that "Sharia-compliant" status get the highest number of first ranking factor of investment decision. In this regard, the respondents are in the opinion that compliance to the Sharia is seen as a very important attribute of an Islamic financial product. Furthermore those who choose Sharia-compliant as the most prominet factor, the majority are from the group of respondents with formal Islamic Economics and Finance education background. The Pearson chi square result suggests that the difference among groups is statistically significant.

The Linkage between Islamic Economics and Finance Courses and Islamic Financial Behavior

The final element of Islamic Financial Literacy is the Islamic Financial Behavior. The behavior here means how respondents actually use Islamic finance products or become customer of Islamic financial institutions. In this section a number of Islamic finance products available in the market are listed. In the first part of the questionnaire, the respondents were asked to give information on which product that they actually and currently use. Moreover, in the second part the respondents were requested to choose which of the Islamic finance product they will use once graduated and gota job. 
As seen fromthe table 6, the general result of Islamic Financial Behavior suggests that Islamic bank saving account is the most chosen product currently and in the future. Having analyzed using the crosstab, the respondents with the exposure of formal Islamic Economics and Finance program are the majority constituents that use Islamic bank saving account. The present study finds that having attended a formal Islamic Economics and Financial courses positively related to a positive opinion towards Islamic finance issue and strong commitment in using Islamic financial services.

\section{CONCLUSION}

It can be observed that most respondents can answer the question correctly in question that asking about example of ribawi transaction (98\%) and the element of aqad (contract) in a transaction (83.7\%). Meanwhile, question on aqad for Islamic bank saving account (6) and characteristic of Islamic mutual funds (7) are the least questions that could be answered correctly $(13.7 \%$ both).The issue of Sharia-compliant got most number one ranking (36.7\%) followed by return (27.3\%) and risk (21\%). The result, therefore, suggests that many respondents put more emphasize on Sharia-compliant status of financial products prior putting their wealth in any Islamic investment schemes. Islamic bank saving account is the most chosen Islamic finance products in the present time as well as in the future time. With respect to the level of Islamic Financial Knowledge, most respondents can be categorized of havingmoderate-knowledge. Hence, the present study finds that attending formal Islamic Economics and Finance courses can positively contribute to a greater level of Islamic Financial Literacy.

\section{LIMITATION}

As this study aims to analyze the impact of Islamic Economics and Finance Courses to the level of Islamic Financial Literacy of university students, it is suggested that future research may investigate this issue using focus group discussion (FGD) and Delphi technique, These two technique to get more insight about the Islamic Financial Literacy from the experts as well as the target respondents.
The Impact of Islamic Economics and Finance

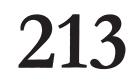


IQTISHADIA

13,2 Case Study of Islamic Banking and Finance Students in Kolej Universiti Islam Antarabangsa Selangor. In The 3rd International Conference on Management \& Muamalah 2016 (Vol. 2016, pp. 277-287).

Atkinson, A., \& Messy, F.-A. (2011). Assessing Financial Literacy in 12 Countries (No. 01/2011-014).

Azmi, M., \& Chong, R. (2014). Financial Literacy : An Exploratory Review of the Literature and Future Research. Journal of Emerging Economies and Islamic Research, 2(3), 2-9.

Bayer, P. J., Bernheim, B. D., \& Scholz, J. K. (2009). the Effects of Financial Education in the Workplace: Evidence From a Survey of Employers. Economic Inquiry, 47(4), 605-624. https://doi.org/10.1111/j.14657295.2008.00156.x.

Blue, L., Grootenboer, P., \& Brimble, M. (2014). Financial literacy education in the curriculum: Making the grade or missing the mark? International Review of Economics Education, 16(PA), 51-62. https://doi. org/10.1016/j.iree.2014.07.005.

Cooper, D. R., \& Schindler, P. S. (2008). Business Research Methods (Internatio). New York: McGraw-Hill/Irwin.

Furqani, H. (2017). Country Reports: The Current Situation oF Islamic Economics. Istanbul. Retrieved from http://www.ikam.org.tr/en/ publications/the-current-situation-of-islamic-economics-in-indonesia.

Hung, A. A., Parker, A. M., \& Yoong, J. K. (2009). Defining and Measuring Financial Literacy (Labor and Population No. WR-708).

Iqbal, Z., \& Mirakhor, A. (2011). An Introduction to Islamic Finance: Theory and Practice (Second edi). Singapore: John Wiley \& Sons Ltd.

Lee, N. (n.d.). What is financial literacy, and does financial literacy education achieve its objectives ? Evidence from banks, government agencies and financial literacy educators in England. London.

Lusardi, A., Mitchell, O. S., \& Curto, V. (2009). Financial Literacy Among the Young : Evidence and Implications For Consumer Policy (No. 15352). Cambridge. 
Mandell, L., \& Klein, L. S. (2009). The Impact of Financial Literacy Education on Subsequent Financial Behavior, (206), 15-24.

Meltzer, H., Bebbington, P., Brugha, T., Jenkins, R., McManus, S., \& Dennis, M. S. (2011). Personal debt and suicidal ideation. Psychological Medicine, 41(4), 771-778. https://doi.org/10.1017/So033291710001261.

Moore, D. L. (2003). Survey of Financial Literacy in Washington State: Knowledge, behavior, Attitudes, and Experiences. Washington State Univer- sity Social and Economic Sciences Research Center Technical Report 03-39. https://doi.org/10.13140/2.1.4729.4722.

OJK. (2018). Laporan Triwulan (Triwulan I-2018). Jakarta.

Otoritas Jasa Keuangan. (2017). Survei Nasional Literasi dan Inklusi Keuangan 2016.

van Rooij, M., Lusardi, A., \& Alessie, R. J. M. (2007). Financial literacy and

\footnotetext{
stock market participation (No. 2007/27). Frankfurt.
}

The Impact of Islamic Economics and Finance

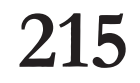

